\title{
THE NITROGEN PARTITION IN NEWBORN INFANTS' URINE
}

\author{
BY
}

\author{
ANDREW BARLOW and R. A. MCCANCE \\ (From the Medical Research Council, Department of Experimental Medicine, Cambridge, England, \\ and Wuppertal, B.A.O.R.)
}

There appears to be very little information on the partition of nitrogen in the urine of infants during the first week of life comparable to the figures produced by Folin (1905a), and by subsequent workers for adult urine. Simon (1911), however, showed that the amino and undetermined nitrogen formed a greater proportion of the total urinary nitrogen in newborn infants than in adults. Schloss and Crawford (1911) measured the total nitrogen, uric acid, and purine excretion in newborn infants, and found that the output of uric acid rose considerably during the first three days of life, and subsequently fell.

Most of the work on nitrogen metabolism in infancy has been done on infants aged two weeks or more, by which time life has become more stable. Colostrum has given place to milk, and the intake of the latter is no longer rising very fast. The physiological dehydration of the first few days has passed, and meconium is no longer being excreted. Studies in nitrogen metabolism made during the first few days of life have, however, a particular value, for they help to bridge the gap between foetal and postnatal metabolism. Unfortunately, the quantities of metabolites excreted during the first few days of life are not necessarily the same as those actually produced by the organism, for Balint and Stransky (1920) and McCance and Widdowson (1947) have shown that the dehydration during the first three or four days of life is accompanied by a rise in the urea and non-protein-nitrogen in the body fluids. Consequently, the end products of nitrogen metabolism will not be excreted so rapidly as they are produced during the first three or four days, and rather more rapidly during the ensuing days.

The present work was undertaken to provide further information on the partition of nitrogen in the urine of very young infants, and on their daily output of certain nitrogenous substances.

\section{Materials and Methods}

Specimens were obtained from the maternity wards of two hospitals in Wuppertal, the Seventy-
Seventh British General Military Hospital, and the Landesfrauenklinik.

No consistent difference was found between the British infants at the military hospital and the German infants at the civilian hospital, although the nutritional status of the German mothers at the latter may not have been altogether satisfactory, since the work was done between the Autumn of 1947 and the Spring of 1948, when' the German population were still on rather a poor diet. Any effect that the nutritional status of the parent may have had upon her offspring was masked by individual variations, and the number of subjects was not large enough for such an effect to receive statistical treatment.

For technical reasons, only male babies were studied. Single untimed specimens were obtained by fixing a test tube over the penis. Continuous collections were made with an apparatus designed by R. F. A. Dean. This consisted of a glass tube $24 \mathrm{~mm}$. in diameter, ample enough to accommodate the penis, moulded and slightly flanged at the upper end to fit closely to the skin without actually touching the penis at all. A hole in the upper surface allowed equilibration of pressure, and prevented the formation of air locks. The lower end was narrowed for the attachment of a rubber tube, which led down to a bottle containing toluene. The whole apparatus was suspended from a belt round the infant's abdomen. Continuous collections have been made for as many as nine days with this apparatus, without any difficulties being encountered.

The urines were collected from normal full-term infants, which were subject to the regular hospital routine. Breast feeding was started twenty-four to thirty-six hours after birth, and no child received any fluid earlier than this. On a single occasion $30 \mathrm{ml}$. of 'tea' was given to each of two babies to supplement their fluid intake during the first day of breast feeding. The urines were preserved with toluene. Protein was found in small quantities in a few specimens, and, when present, was removed by filtration after boiling with a few drops of glacial acetic acid.

The total nitrogen was estimated by the microkjeldahl method, using copper selenide and copper sulphate as catalysts. Ammonia was estimated on the day of collection, before removal of protein 
TAERE 1

A COMPARISON OF THE CONCENTRATIONS OF TOTAL NITROGEN AND OF THE NITROGEN PARTITION IN INFANT AND ADULT URINES

\begin{tabular}{|c|c|c|c|c|c|c|c|c|}
\hline \multirow[b]{2}{*}{ Age and diet } & \multirow{3}{*}{$\begin{array}{c}\begin{array}{c}\text { No. } \\
\text { of } \\
\text { subjects }\end{array} \\
11\end{array}$} & \multirow{3}{*}{$\begin{array}{c}\begin{array}{c}\text { A verage } \\
\text { total } \\
\text { nitrogen } \\
\text { mg./100 ml. } \\
\text { urine }\end{array} \\
97\end{array}$} & \multicolumn{6}{|c|}{ These figures are expressed as percentage of the total nitrogen } \\
\hline & & & Urea & $\underset{\mathbf{N}}{\text { Ammonia }}$ & $\underset{\mathbf{N}}{\text { Creatinine }}$ & $\underset{\mathbf{N}}{\text { Creatine }}$ & $\underset{\mathbf{N}}{\text { Uric acid }}$ & $\begin{array}{l}\text { Undeter- } \\
\text { mined } \\
\mathbf{N}\end{array}$ \\
\hline At birth $\quad$. $\quad$. & & & $71 \cdot 1$ & $5 \cdot 4$ & $3 \cdot 4$ & $2 \cdot 0$ & $4 \cdot 9$ & $13 \cdot 2$ \\
\hline $0-12$ hours ... & $\$ 2$ & 468 & $56 \cdot 9$ & $7 \cdot 2$ & $4 \cdot 1$ & 1.9 & $5 \cdot 8$ & $24 \cdot 1$ \\
\hline $12-24$ hours & 10 & 704 & $60 \cdot 4$ & $8 \cdot 5$ & $5 \cdot 4$ & $2 \cdot 1$ & $5 \cdot 6$ & $18 \cdot 0$ \\
\hline 48-72 hours: breast milk & 12 & 812 & $65 \cdot 5$ & $7 \cdot 0$ & 3.9 & $2 \cdot 1$ & $4 \cdot 0$ & $17 \cdot 5$ \\
\hline $\begin{array}{rlr}\text { Adults : normal } & \text { (present } \\
\text { investigation) } & \cdots & \ldots\end{array}$ & 10 & 919 & $82 \cdot 7$ & $4 \cdot 6$ & $3 \cdot 7$ & 1.0 & $1 \cdot 6$ & $6 \cdot 4$ \\
\hline \begin{tabular}{cccc} 
Aduits : & normal & \multicolumn{2}{c}{ (Folin, } \\
1905a) & $\cdots$ & $\cdots$ & $\cdots$ \\
\end{tabular} & 6 & - & $87 \cdot 5$ & $4 \cdot 3$ & $3 \cdot 6$ & - & 0.8 & $3 \cdot 8$ \\
\hline $\begin{array}{cccc}\text { Adult: } & \text { Normal (Cathcart, } \\
\text { 1907) } & . & \ldots & \ldots \\
\end{array}$ & 1 & - & $87 \cdot 1$ & $3 \cdot 6$ & $3 \cdot 2$ & 0.1 & $1 \cdot 0$ & $5 \cdot 0$ \\
\hline $\begin{array}{l}\text { Adult: 14th day of starva- } \\
\text { tion (Cathcart, 1907) }\end{array}$ & 1 & - & 77 & $9 \cdot 4$ & $3 \cdot 1$ & $1 \cdot 3$ & $2 \cdot 2$ & $7 \cdot 0$ \\
\hline $\begin{array}{l}\text { Adult: 21st day of starva- } \\
\text { tion (Benedict, see } \\
\text { Lusk, 1928) } \\
\end{array}$ & 1 & - & 69.9 & $19 \cdot 8$ & $4 \cdot 8$ & & 1.4 & $4 \cdot 1$ \\
\hline $\begin{array}{l}\text { Adults: high-calorie-low- } \\
\text { protein (Folin, 1905b) }\end{array}$ & 3 & - & 60.6 & $9 \cdot 7$ & 15 & - & $3 \cdot 2$ & $11 \cdot 5$ \\
\hline $\begin{array}{l}\text { Adults: high-caloric-low- } \\
\text { protein (Robison, 1922) }\end{array}$ & 2 & - & 48 & $11 \cdot 1$ & $21 \cdot 7$ & - & $3 \cdot 4$ & 15.8 \\
\hline
\end{tabular}

(if present), by the microdiffusion method of Conway and Byrne $(1933,1935)$. Urea was estimated by the method of Archibald (1945) and, since a high degree of accuracy was required in view of the large proportion of urea in the total nitrogen, some determinations were also made by the urease method of van Slyke and Cullen (1914) with very good agreement. Creatinine and creatine were estimated by the method of Folin and Wu(1914). Uric acid was estimated by the method of Benedict and Franke (1922), but since the results obtained by this method were somewhat lower than those previously reported for uric acid in infants' urines (Schloss and Crawford, 1911), a number of estimations were also performed by the silver nitrate precipitation method of Folin (1933). The values given by the latter method averaged slightly less than those given by Benedict and Franke's direct method, but in no case would the difference between the two methods involve an alteration in the undetermined nitrogen greater than 1 per cent. Further confirmation that the uric acid values were correct was provided by the determinations of purine nitrogen which, in most cases, only slightly exceeded the uric acid nitrogen. If the urines had contained as much uric acid as those reported in the literature, they would have held more uric acid nitrogen than the total purine nitrogen, which would have been absurd. The total purine nitrogen was estimated by the method of Hitchings and Fiske (1941). The free amino nitrogen was estimated by Frame et al's (1943) modification of the method of Folin (1922), and combined amino nitrogen by the same method after hydrolysis with 20 per cent. hydrochloric acid or 20 per cent. sodium hydroxide for one hour. Acid and alkaline hydrolysis released practically the same amount of amino nitrogen from aliquots of the same urine.

Results

Table 1 shows the total nitrogen in $\mathrm{mg}$. per $100 \mathrm{ml}$. of urine, and the nitrogen partition in specimens of urine passed at birth, in the next twelve hours of life, between the twelfth and twenty-fourth hour, and between the forty-eighth and seventy-second hour. Data obtained by the same methods on the urines of five men and five women on normal diets are also given. Figures obtained from the literature for adults on normal diets (Folin, 1905a), under conditions of starvation (Cathcart, 1907; Benedict, quoted by Lusk, 1928), and on high-calorie-low-protein diets (Folin, 1905b; Robison, 1922). It will be seen that the present findings for normal adult urines are in fairly good agreement with those of Folin (1905a) and of Cathcart (1907).

The eleven urines passed at birth were produced within a few minutes of the baby leaving the uterus, and were formed there. It can be seen from table 1 that the quantity of nitrogen per $100 \mathrm{ml}$. was extremely small. During the first few days the concentration of total nitrogen increased, and the highest average was reached between the forty-eighth and the seventy-second hour, when physiological dehydration is usually greatest, but even at this time the urine contained less nitrogen per $100 \mathrm{ml}$. than the average daily urine of an adult. 
TACE 2

THE PURINE AND AMINO NITROGEN IN INFANT AND ADULT URINES

\begin{tabular}{|c|c|c|c|c|c|c|c|c|c|}
\hline & $\begin{array}{l}\text { No. of } \\
\text { specimens }\end{array}$ & $\begin{array}{c}\text { Tocal } \\
\text { nitrogen } \\
\text { mg/ } / 100 \mathrm{ml} . \\
\text { urine }\end{array}$ & $\begin{array}{c}\text { Purines } \\
\text { other than } \\
\text { uric acid } \\
(\% \text { of T.N.) }\end{array}$ & $\begin{array}{c}\text { No. of } \\
\text { specimens }\end{array}$ & $\begin{array}{c}\text { Total } \\
\text { nitrogen } \\
\text { mg-/ } 100 \mathrm{ml} . \\
\text { urine }\end{array}$ & $\begin{array}{l}\text { Amino } \\
\text { nitrogen } \\
\% \text { of } T . N .\end{array}$ & $\begin{array}{l}\text { No. of } \\
\text { specimens }\end{array}$ & $\begin{array}{l}\text { Total } \\
\text { nitrogen } \\
\text { mg./100 ml. } \\
\text { urine }\end{array}$ & $\begin{array}{l}\text { Amino } \\
\text { nitroyen } \\
\text { released by } \\
\text { hydrolysis } \\
\text { (\% of T.N.) }\end{array}$ \\
\hline Infants, 0-24 hrs. .. & 5 & 559 & $1 \cdot 57$ & 10 & 476 & $3 \cdot 3$ & 5 & 543 & 0.9 \\
\hline Infants, $24-48$ hrs. & 5 & 661 & $1 \cdot 4$ & 10 & 646 & $2 \cdot 6$ & - & - & - \\
\hline Adults, normal diet & 6 & 870 & $0 \cdot 35$ & 5 & 842 & 0.9 & 5 & 925 & 0.5 \\
\hline
\end{tabular}

The partition of nitrogen in infants' urines differed considerably from that in the urine of adults on a normal diet, for (1) the urea formed a much smaller percentage of the total nitrogen, so much so that the ranges of individual variation did not overlap. The data for normal adult urines taken from the literature show that the figure now given for adults was not unusually high; it was, in fact, lower than that of Folin or of Cathcart. (2) The ammonia formed a significantly greater percentage of the total nitrogen, a finding which agrees with that of McCance and von Finck (1947), who found in their series also that the difference was statistically significant. (3) The creatinine accounted for very nearly the same percentage of the total nitrogen. Since these infants (see later) excreted less total nitrogen per $\mathrm{kg}$. of body weight per day than adults did, this means that they also excreted less creatinine per kg. of body weight, an observation which agrees with the one made by Rose in 1911. (4) The creatine nitrogen made up a higher percentage of the total nitrogen.
This was to be expected, since men have been said to excrete no creatine. Actually, in this work, both men and women were found to excrete similar but very small amounts. (5) The uric-acid nitrogen accounted for about three times as much of the total nitrogen, and (6) the undetermined nitrogen made up a much greater percentage of the total nitrogen. It varied inversely, as might have been expected, with the percentage excreted as urea, and reached the remarkably high average figure of 24 per cent. in the first twelve hours of life.

Table 2 contains a partial analysis of the ' undetermined ' nitrogen of infant and adult urines. It will be seen that the nitrogen of purines other than uric acid, and of free and conjugated amino acids, made up a greater proportion of the total nitrogen in the infants' than in the adults' urines, but these findings did not account for very much of the undetermined nitrogen.

When the figures for infants in table 1 are compared with those drawn from the literature for

TARE 3

VARIATIONS IN THE DAIIY OUTPUT OF TOTAL NITROGEN, UREA, AND URIC ACID DURING THE FIRST WEEK OF LIFE, AND A COMPARISON WITH ADULTS

\begin{tabular}{|c|c|c|c|c|c|c|c|c|c|c|}
\hline & \multirow[b]{3}{*}{$0-48$} & \multirow[t]{3}{*}{ nts: age } & \multirow[b]{3}{*}{$96-144$} & \multicolumn{7}{|c|}{ Adults and diet } \\
\hline : & & & & \multicolumn{3}{|c|}{ Normal diet } & \multicolumn{2}{|c|}{ Starvation } & \multicolumn{2}{|c|}{$\begin{array}{c}\text { High-caloric- } \\
\text { low-protein }\end{array}$} \\
\hline ? & & & & $\begin{array}{c}4 \text { adults } \\
\text { present } \\
\text { investiga- } \\
\text { tion }\end{array}$ & $\begin{array}{c}\text { Folin } \\
\text { (1905a) } \\
6\end{array}$ & $\begin{array}{c}\text { Cathcart } \\
\text { (1907) } \\
1\end{array}$ & $\begin{array}{c}\text { Cathcart } \\
\text { (1907) } \\
1\end{array}$ & $\begin{array}{c}\text { Benedict } \\
(1915) \\
1\end{array}$ & 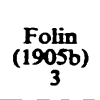 & $\begin{array}{c}\text { Robison } \\
\text { (1922) } \\
2\end{array}$ \\
\hline Total nitrogea mg/day & $119 \cdot 8$ & $147 \cdot 6$ & $190 \cdot 7$ & 11,715 & 16,000 & 15,970 & 7,780 & 7,930 & 3,300 & 2,070 \\
\hline Urea nitrogen mg/day! & $68 \cdot 4$ & $89 \cdot 2$ & $123 \cdot 6$ & 9,627 & 13,900 & 13,520 & 5,990 & 5,540 & 2,000 & 995 \\
\hline $\begin{array}{c}\text { Uric acid nitrogen } \\
\text { ms/day } \ldots\end{array}$ & 6 & 6 & $6 \cdot 8$ & 166 & 120 & 157 & 170 & 112 & 103 & 70 \\
\hline $\begin{array}{c}\text { Urea nitrogen as } \% \text { of } \\
\text { total nitrogen }\end{array}$ & $59 \cdot 4$ & $64 \cdot 3$ & $67 \cdot 9$ & 82 & $87 \cdot 5$ & $87 \cdot 1$ & 77 & 69.9 & $60 \cdot 6$ & 48 \\
\hline $\begin{array}{ccc}\text { Uric acid nitrogen as } \\
\% \\
\% \text { of total nitro- } \\
\text { \% }\end{array}$ & $7 \cdot 3$ & $4 \cdot 4$ & $3 \cdot 7$ & $1 \cdot 4$ & 0.8 & $1 \cdot 0$ & $2 \cdot 2$ & $1 \cdot 4$ & $3 \cdot 2$ & $3 \cdot 4$ \\
\hline $\begin{array}{c}\text { Total nitrogen me/kg/ } \\
24 \mathrm{hrs} .\end{array}$ & $30 \cdot 5$ & $38 \cdot 6$ & $49 \cdot 9$ & 203 & 255 & 242 & 135 & 158 & $47 \cdot 3$ & $34 \cdot 4$ \\
\hline 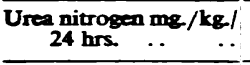 & $18 \cdot 3$ & $25 \cdot 1$ & $33 \cdot 9$ & 167 & 223 & 212 & 104 & 112 & $28 \cdot 6$ & $16 \cdot 5$ \\
\hline $\begin{array}{c}\text { Uric acid nitrogen me/ } \\
\text { ke } / 24 \text { hrs. }\end{array}$ & $1 \cdot 6$ & $1 \cdot 7$ & $1 \cdot 8$ & 2.9 & $2 \cdot 0$ & $2 \cdot 4$ & $2 \cdot 9$ & $2 \cdot 2$ & 1.5 & 1.6 \\
\hline
\end{tabular}


adults on abnormal dietary regimes, certain interesting points emerge. (1) The percentage of the total nitrogen excreted as urea by adults has been found to be lower in starvation than on normal diets, and to be lower still on high-calorie-low-protein diets. The figures for infants lay between the starvation and low protein levels for adults. (2) The percentage of the total nitrogen excreted as ammonia by starving adults, and by adults on high-calorie-lowprotein diets has been found to be higher than normal, and the figures obtained were somewhat higher than those now being reported for infants. (3) The percentage of the total nitrogen excreted as creatinine by infants is similar to that excreted by starving adults, but very much lower than that excreted by adults on high-calorie-low-protein diets. (4) The percentage of the total nitrogen excreted as uric acid by infants was not only higher than that excreted by normal adults, but somewhat higher than that excreted by starving adults or adults on a high-calorie-low-protein diet.

Further reference to table 1 shows that the percentage of the total nitrogen excreted as urea by the infants varied with age. Thus at birth it was $71 \cdot 1$ per cent., in the next twelve hours it fell to 56.9 per cent., and on the third day rose to 65.5 per cent., and these differences were statistically significant $(t=2.69, p=0.02 ;$ and $t=2.45$, $\mathbf{p}=\mathbf{0 . 0 3}$ respectively). As may be seen from table 3, the rise continued at least until the sixth day.

Table 3 shows the average total nitrogen, urea, and uric acid nitrogen excreted in twenty-four hours by eight infants during the first six days of their lives in three periods of two days each. The average amounts of these substances excreted in single twenty-four hour specimens by three men and one woman on normal diets, and figures obtained from the literature for the excretion of the same metabolites by adults on abnormal dietary regimes are also given. The upper part of the table shows the excretion in mg. per twenty-four hours, the middle part the percentages of the total nitrogen formed by urea and uric acid, and the lower part the excretion of these substances in $\mathrm{mg}$. per $\mathrm{kg}$. of body weight per twenty-four hours. The results were not obtained from the same specimens of urine as those given in table 1 , but they show the same features. The urea formed a considerably lower percentage of the total nitrogen than it did in adults on normal diets, and there was again a rise between the first two and the last two days of the period of observation. The percentage of the total nitrogen made up by uric acid was considerably greater than in normal adults, but it tended to fall and was only slightly higher at the close of the period of observation than in adults on high-calorie-low-protein diets.

There was sometimes considerable variation in the amount of total nitrogen excreted by the same infant from day to day, but it is not thought possible that this was due to spilling of part of the urine, for when this did happen in other infants it was made obvious by the dampness of the napkin surrounding the collecting apparatus. It is thought that these day-to-day variations were due to irregularities in the times at which the infant voided its urine and to retention in the bladder of variable amounts, so that urine secreted during one twentyfour hour period was collected with the next.

Table 3 also makes it clear that (1) the daily excretion of total and of urea nitrogen tended to rise, but it was always much lower per kg. of body weight per twenty-four hours in the infants than in the normal or the starving adults, and was about equal to the figures which have been found for adults on a high-calorie-low-protein diet. (2) The infants excreted less uric acid per $\mathrm{kg}$. of body weight per twenty-four hours than normal or starving adults, but about the same amount as adults on a highcalorie-low-protein diet. The amount excreted per day was nearly constant, a finding which directly conflicts with that of Schloss and Crawford (1911). The difference may lie in the technique by which the urine was collected and sampled (see above), or by which the uric acid was estimated, or even in the dietary treatment of the children (Reusing, 1895; Birk, 1911). As already stated, the figures obtained for infants in the present investigation were lower than those obtained by Reusing or Simon, or by Schloss and Crawford, but no studies of the uric acid metabolism in the first week of life have appeared since the more modern chemical techniques were introduced. The figures obtained for adults in this study, however, were in complete agreement with those of others (table 3 ).

\section{Discussion}

A comparison of the amounts and types of nitrogenous compounds excreted by infants and adults has brought out certain differences and similarities. These are clearly not all due to one and the same cause, but a number of them can be explained in terms of what is already known about metabolism. In adults on a normal diet the excretion of nitrogen is high because the protein intake is generous and little or none of the nitrogen is being retained or excreted by extra-renal channels (Lancet, 1937). The excretion of nitrogen may also be very high, due to the destruction of body protein which follows trauma or burns. It falls during starvation because the breakdown of protein is not so rapid at that time as it is after trauma, or during periods of luxus consumption and higher metabolic rates. It falls greatly on high-calorie-low-protein diets, because the high intakes of sugar and fat reduce the breakdown of body protein for gluconeogenesis.

The percentage of the total nitrogen in the urine present as urea is high in normal adults, or in adults after trauma, because the catabolism of protein is sufficiently rapid to ensure that the urinary nitrogen is greatly in excess of the amount required for the prior charges, such as ammonia and creatinine. This statement is true regardless of the theories which may at any time be held about the sources 
of these compounds. The percentage falls in starvation because the amount of nitrogen required for the prior charges falls less than the quantity of nitrogen set free from the protein catabolized, and this tendency is accentuated by a high-calorie-lowprotein diet. In other words, in the absence of disturbing factors such as acidosis, the greater the amount of nitrogen to be excreted, the greater will be the percentage of that nitrogen excreted as urea and the smaller will be the percentage excreted as ammonia or creatinine.

Total nitrogen. For the first forty-eight hours of a breast-fed infant's life its output of nitrogen would be expected to be low (a) because it is starving, (b) because its total expenditure of energy at that time is small, and therefore the breakdown of tissue protein is likely to be correspondingly small, and (c) because the kidney does not excrete all the nitrogen which is broken down. Furthermore, the ratio of nitrogen excreted to nitrogen ingested is likely to be lower in infants than in adults, because the dietary nitrogen will always tend to be used to increase the mass of body protein. This is not important during the first forty-eight hours of life, because the ingestion of food is so small at that time; but, on intakes of nitrogen and calories which are adequate in terms of body weight, infants would be expected to excrete less nitrogen than adults, and to excrete a smaller percentage of that nitrogen as urea.

One can, therefore, explain along these lines why the output of nitrogen per $\mathrm{kg}$. of body weight in infants should bear the relationship it has been found to do to normal and starving adults, and to adults who have been placed on high-calorie-low-protein diets. It would appear from table 3, however, that in the critical days after birth the amount of nitrogen excreted per twenty-four hours increases with age. This rise can be explained in a similar way, for in the first two days of life the baby is starving, and becoming dehydrated, whereas at the end of the first week it is taking a sufficient quantity of food and fluid to meet practically all its excretory and metabolic requirements.

Urea nitrogen. For the reasons already given, the percentage of the total nitrogen excreted by infants as urea would be expected to be lower at all times than that excreted by normal adults, but it also varies in an interesting way with age within the first week (tables 1 and 3 ). $71 \cdot 1$ per cent. of the nitrogen in the urine formed in utero was present as urea, and it is suggested that this is an expression of the fact that the urine came from a well-fed but actively growing organism. It was mainly the active growth which kept the percentage of the total nitrogen excreted as urea below that of normal adults. With the onset of starvation the percentage excreted as urea fell, for the reasons already given for its fall in starving adults. There was no significant difference between the percentage excreted as urea in the first and second twelve hours of life, but the lower figure obtained for the first twelve hours may possibly have been due to the fact that the baby was born with a sufficient store of glycogen in its liver to delay gluconeogenesis for that period of time. A significant rise in the percentage of the total nitrogen excreted as urea was, however, apparent by the third day, by which time the infants were beginning to take a relatively high protein diet and the output of nitrogen was increasing. It would appear from table 3 that the rise in the output of nitrogen, and therefore in the percentage of that nitrogen excreted as urea, continues for some time after birth.

Ammonia nitrogen. The percentage of the total nitrogen found to be excreted as ammonia by normal adults in the present investigation is close to that found by Folin (1905a) and Cathcart (1907), but below the percentage excreted as ammonia in adults who are starving or taking high-calorie-lowprotein diets. The rise in starvation has generally been accepted as due to the acidosis (Lusk, 1928) and the increase on high-calorie-low-protein diets to the small amount of total nitrogen in the urine. However, examination of the figures of Folin and of Cathcart for adults on normal and on high-calorielow-protein diets reveals that the actual quantity of ammonia excreted per $\mathrm{kg}$. of body weight in twentyfour hours is lower on the latter (averaging $10 \mathrm{mg}$. per $\mathrm{kg}$. per twenty-four hours on normal, and 5 to $6 \mathrm{mg}$. per $\mathrm{kg}$. per twenty-four hours on highcalorie-low-protein diets). The high figures in infancy were attributed by McCance and von Finck to the fact that the urine at this age contained so little inorganic phosphate. From the point of view of ammonia production this is equivalent to an acidosis, because, if the urine is to be maintained above pH5 in the absence of the usual buffering substances, much more of the acids have to be excreted as their ammonium salts. There may also be a real acidosis at that age, but even if there is the quantity of ammonia excreted per $\mathrm{kg}$. per twentyfour hours remains less in infants than in normal adults, for table 1 shows that the percentage of the total nitrogen formed by ammonia in infants' urine is not more than double that in normal adults' urine, and table 3 shows that the total nitrogen excreted per kg. body weight in twenty-four hours by normal adults is at least four times that excreted by infants, even at the end of the first week of life.

Uric acid nitrogen. In infancy the large percentage of the total nitrogen excreted as uric acid at once arrests attention. This is not due to a large production of uric acid per $\mathrm{kg}$. of body weight as the appearance of an infant's urine on the second day of life might suggest, or as the deposits of uric acid in the kidney of the newborn have led many to suppose. Actually, the excretion of uric acid per kg. of body weight is lower in infants than in adults, except when the latter are on high-calorie-lowprotein diets. This may be partly an expression of the fact that an infant's food is practically purinefree. At all events physicochemical conditions in the urine rather than the large amounts of urates there must underlie the ready deposition of urates from 
infant urines. The high percentage of the total nitrogen excreted as uric acid in infancy must be attributed primarily to the fact that the total nitrogen excreted per kg. of body weight is so low, and the reasons for this have already been discussed. It is certainly not due, as it may be in adults, to a highcalorie-low-protein diet. There is no doubt, however, that the ratio of uric acid nitrogen to urea or to total nitrogen in the urine is very much higher in early infancy than in later life, and this suggests that infants may convert more of the available amino acids to purines than adults do, in other words that their purine metabolism is relatively more intense.

Undetermined nitrogen. The percentage of the total nitrogen unaccounted for in the urine of infants is remarkably high, and is only approached by adults who are on high-calorie-low-protein diets. It has been shown that this large fraction cannot be accounted for as purines other than uric acid, or as amino nitrogen, either free or combined. It may, as with uric acid, be due partly to the very small output of total nitrogen, but the nature of this undetermined nitrogen awaits investigation. There are indications, however, that the quantities and amounts of the different amino acids which are excreted at this age may differ considerably from those found in later life, and this matter is being studied at the present time.

\section{Summary}

1. The total nitrogen in urine formed in utero averaged less than $100 \mathrm{mg}$. per $100 \mathrm{ml}$. When physiological dehydration was greatest the total nitrogen averaged $812 \mathrm{mg}$. per $100 \mathrm{ml}$., but this was not so high as the average figure found in normal adult urine.

2. During the first week of life the outputs of total and urea nitrogen, expressed as $\mathrm{mg}$. per $\mathrm{kg}$. of body weight per day, tended to rise but were always much lower than they were in normal or starving adults. They were about equal to the outputs of adults on high-calorie-low-protein diets. The output of uric acid nitrogen in mg. per kg. per day was also much lower than in normal or starving adults, but there was no tendency for it to rise.

3. When the partition of nitrogen in infants' urine was compared with that in normal adults' urine it was found that (a) the percentage present as urea was lower, (b) the percentage present as ammonia, uric acid, and undetermined nitrogen was higher, (c) the percentage present as creatinine was about the same.

4. The percentage of the total nitrogen present as urea was significantly higher in the urine formed in utero and after the third day of life than in that passed in the first two days of life.

5. By comparing these results with those for starving adults and for adults on high-calorie-lowprotein diets, and by taking into account what is known of the nitrogen metabolism of adults and infants, most of these findings can be explained.

The authors are very grateful for the help and kindness of Col. Mackay Dick and of Prof. K. J. Anselmino, and wish to thank the sisters and nurses at the Seventy-Seventh British General Military Hospital and at the Landesfrauenklinik for their co-operation.

\section{REFERENCES}

Archibald R. M. (1945). J. biol. Chem., 157, 507.

Balint, A., and Stransky, E. (1920). Jb. Kinderheilk., 93, 210.

Benedict, S. R., and Franke, E. (1922). J. biol. Chem., 52, 387 .

Birk, W. (1911). Mschr. Kinderheilk., 10, 1.

Cathcart, E. P. (1907). Biochem. Z., 6, 109.

Conway, E. J. (1935). Biochem. J., 29, 2755.

Conway, E. J., and Byrne, A. (1933). Biochem. J., 27, 419.

Folin, O. (1905a). Amer.J. Physiol., 13, 45. (1905b). Ibid., 13, 66.

(1914). J. biol. Chem., 17, 469.

(1933). Ibid., 101, 111.

, and Wu, H. (1922). Ibid., 51, 377.

Frame, E. G., Russell, J. A., and Wilhelmi, A. E. (1943). Ibid., 149, 255 .

Hitchings, G. H., and Fiske, C. H. (1941). Ibid., 140, 491.

Lancet (1937), 1, 936.

Lusk, G. (1928). The Elements of the Science of Nutrition. Fourth Edit. W. B. Saunders Co. Philadelphia and London.

McCance, R. A., and von Finck, M. A. (1947). Arch. Dis. Childh., 22, 200.

, and Widdowson, E. M. (1947). Lancet, 1, 787.

Reusing, H. (1895). Z. Geburtsh. Gynäk., 33, 36.

Robison, R. (1922). Biochem. J., 16, 131 .

Rose, W. C. (1911). J. biol. Chem., 10, 265.

Schloss, O. M., and Crawford, J. L. (1911). Amer. J. Dis. Child., 1, 203.

Simon, S. (1911). Z. Kinderheilk., 2, 1.

Slyke, D. D. Van, and Cullen, G. E. (1914). J. biol. Chem., 19, 211. 